turally or petrologically, since they lack the characteristic sheeted dyke complex, gabbros and ultramafic assemblage. We have, in fact, never used the word 'ophiolite' in our publications, out of the simple recognition of the fact that such a complex in its entirety does not appear to exist within Norway: at least, none has been confirmed to date. There are pointers, however, one of which is the recent recognition of obducted hawaiitic volcanics associated with ultramafites on the island of Leka, $200 \mathrm{~km}$ NNE of Trondheim (Prestvik, 1974). Also, mafic dykes associated with gabbro and ocean floor-type lavas are known from certain areas, e.g. the Lokken area. Other fragments or slices of what may represent original ophiolite complexes may occur at other places in central Norway. There are some indications of this, but since detailed studies are lacking it would be premature even to speculate on these occurrences at this stage.

\title{
References
}

Dewey, J. F. 1969. Evolution of the Appalachian/Caledonian orogen. Nature, Lond. 22, $124-9$.

Gale, G. H. \& Roberts, D. 1972. Palaeogeographical implications of greenstone petrochemistry in the southern Norwegian Caledonides. Nature Phys. Sci., Lond. 238, 60-1.

Gale, G. H. \& Roberts, D. 1974. Trace element geochemistry of Norwegian Lower Palaeozoic basic volcanics and its tectonic implications. Earth Plan. Sci. Lett. 22, 380-90.

Mason, R. 1974. The location of the Iapetus suture in the Scandinavian Caledonides. Geol. Mag. 111, 439-42.

Nicholson, R. 1971. Faunal provinces and ancient continents in the Scandinavian Caledonides. Bull. geol. Soc. Am. 82, 2345-56.

Nicholson, R. 1974. The Scandinavian Caledonides. In Nairn, A. E. M. \& Stehli, F. G. (Eds.): The Ocean Basins and Margins, vol. 2, 161-203.

Prestvik, T. 1974. Supracrustal rocks of Leka, Nord-Trøndelag. Norg. geol. unders. 311, 65-87.

Roberts, D. 1971. Timing of Caledonian evorogenic activity in the Scandinavian Caledonides. Nature Phys. Sci., Lond. 232, 22-3.

Smithson, S. B. \& Ramberg, I. B. 1970. Geophysical profile bearing on the origin of the Jotun nappe in the Norwegian Caledonides. Bull. geol. soc. Am. 81, 1571-6.

Smithson, S. B., Ramberg, I. B. \& Grønlie, G. 1974. Gravity interpretation of the Jotun nappe of the Norwegian Caledonides. Tectonophysics, 22, 205-22.

Norges Geologiske Undersøkelse

DAVID ROBERTS

Trondheim

Norway

22nd November 1974

\section{The Cwm Dulyn rhyolite, Snowdonia}

SIR - Dr Wright has written concerning the possible extrusive nature of the Cwm Dulyn rhyolite dome. I share his expectations that extrusive rhyolite bodies not only occur but also may eventually be proven to occur in the Ordovician of Snowdonia. It is important therefore to evaluate as best we can the 3 pieces of evidence he presents in favour of an extrusive as opposed to an intrusive origin for the Cwm Dulyn dome (Wright, 1974).

\section{The overall field relations}

He states that the ignimbrite sheet has a quite gentle southerly dip in the immediate vicinity of the dome and refers the reader to his figure 2 as the evidence in support of this statement. It needs to be pointed out, however, that Wright's figure 2 is a near

Geol. Mag. 112 (4), 1975, pp. 416-418. Printed in Great Britain. 
perfect strike section and so it is hardly suprising that the ignimbrite sheet is shown with but a very gentle apparent dip. It is true that the near-uniform attitude of the columnar jointing in the ignimbrite in close proximity to the dome could lead to the inference that the eutaxitic structure remains undisturbed. This, however, is far from the case (see Roberts, 1967, p. 383, for an illustration of how misleading such an assumption can sometimes be). In fact Figure 1, based on my field slips, shows that dips in the eutaxitic structure in the ignimbrite adjacent to the dome range from horizontal to vertical and that there is a pronounced swing in strike of the eutaxitic structure in the ignimbrite around the dome. Away from the dome the eutaxitic structure dips uniformly southeast into the Llwyd Mawr Syncline.

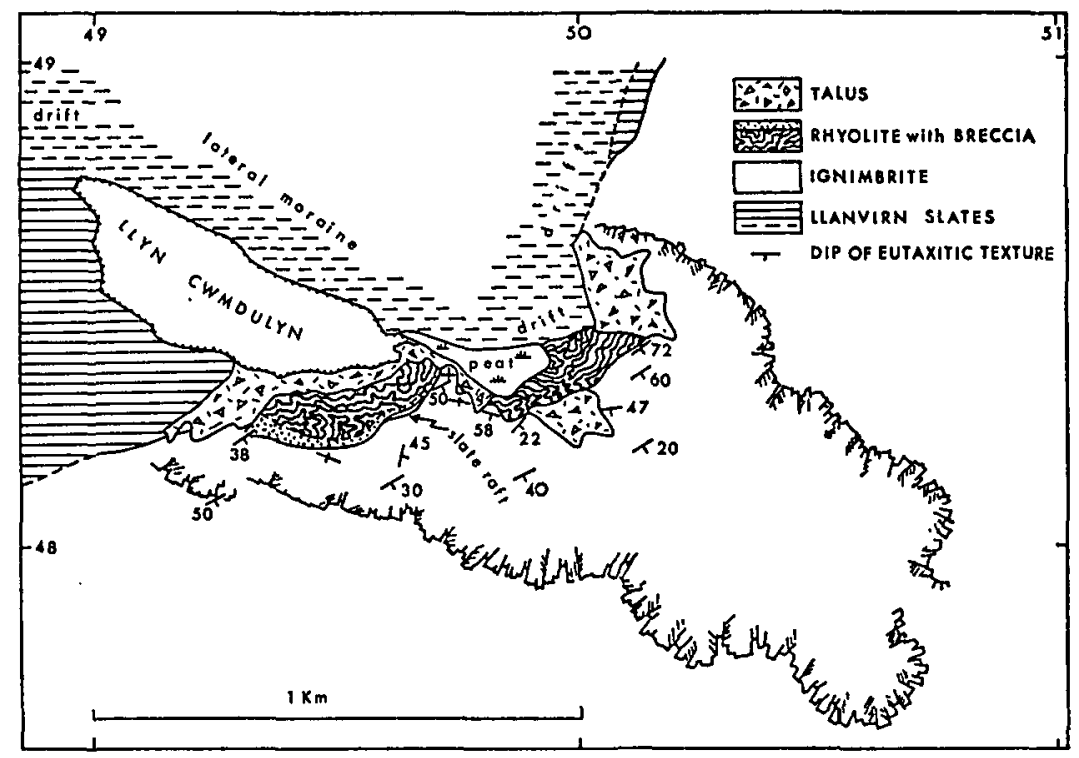

Figure 1. Map showing the field relations of the Cwm Dulyn rhyolite dome.

\section{The rubbly brecciated outer surface of the rhyolite}

This reminds Wright of the Jurassic extrusive rhyolites of northern Nigeria. Unfortunately I have not had the same opportunity of examining those particular bodies but I am struck by the fact that this Ordovician envelope is of fairly constant thickness at about 6-7 m. It seems to me that if the steep-sided Cwm Dulyn dome had been extruded to a height of over $100 \mathrm{~m}$, as the hypothesis of extrusion requires, then the brecciated margin could be expected to spall off and take on the form and angle of rest of a talus. There is no indication that this has happened.

\section{The presence of fragments of sparsely porphyritic marginal rhyolite}

Such lithic fragments, within crystal-rich ingimbrite near the contact, along with chips of pelite, are commonplace near the base of the ignimbrite sheet over its entire outcrop and are not confined simply to the immediate vicinity of the dome as Wright implies.

Another point he makes needs to be taken up. Figure 1 indicates that the $\mathrm{N}$ shore of Llyn Cwmdulyn at its southeastern end is entirely drift-covered and therefore Wright is unjustified in concluding that 'it seems to be made entirely of rhyolite'. The fact that the cover of morainic debris is largely of boulders of flow-banded rhyolite is only to be 


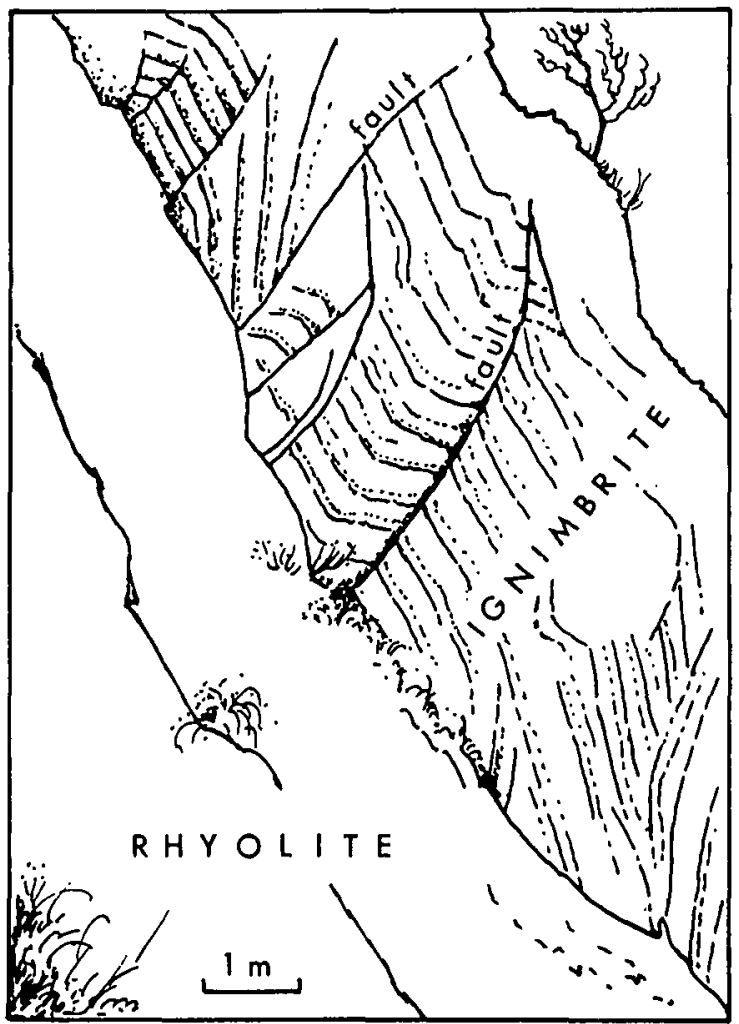

Figure 2. Drawing (from a photograph) showing a steep contact between rhyolite and ignimbrite at the western extremity of the dome. The ignimbrite is faulted and its columnar jointing is bent and smashed.

expected given the directions of ice movement in the area of Cwm Dulyn and the present disposition of the outcrops of rhyolite.

Interesting though Wright's statements are I do not consider them to be evidence in support of his conclusion. My reasons for continuing to regard the dome as intrusive are: the fact that near the feebly welded base of the ignimbrite sheet the eutaxitic structure has been displaced by the rhyolite dome (Fig. 1); that where the rhyolite is adjacent to higher and more strongly welded horizons of the ignimbrite the columnar jointing of the ignimbrite is bent and smashed (Fig. 2); and the presence of small rafts of blue-black slate up to $10 \mathrm{~cm}$ thick and $5 \mathrm{~m}$ long caught up at intervals along the junction.

\section{References}

Roberts, B. 1967. Succession and structure in the Llwyd Mawr syncline, Caernarvonshire, North Wales. Geol. J. 5, 369-90.

Wright, J. B. 1974. The Cwm Dulyn rhyolite, Snowdonia - an extrusive dome? Geol. Mag. 111, 444-6.

B. ROBERTS

Geology Department

Birkbeck College

(London University)

7-15 Gresse Street

London W1 IPA

12th December 1974 